\title{
THE DOWNFALL OF THE RUSSIAN AND AUSTRO-HUNGARIAN EMPIRES AND THE MONARCHIST COUNTER-REVOLUTION*
}

\author{
Dmytro Bondarenko \\ University of Szeged, \\ Szeged, Hungary
}

The aim of this article is to offer a comparative analysis of the revolutionary dissolution of the Russian and the Austro-Hungarian Empires, and also to study the process of revolution-counter-revolution, in particular, the origins, classification, and results of the monarchist counter-revolution witnessed in the territories of the former Empires. The monarchist counter-revolution in Central and Eastern Europe emerged in these countries (Russia, Hungary, Finland) precisely as a response to Soviet power and Bolshevism, as an ideology and political practice. It would not have had a serious basis during the democratic republican period of the revolution that preceded Bolshevism. The factors involved in the emergence of a monarchist counter-revolution include the following: the existence of strong monarchist traditions in society, the presence of charismatic military and political leaders who professed monarchical views (for example, LieutenantGeneral Baron Carl Gustaf Emil Mannerheim in Finland, Lieutenant-General Pavlo Skoropadsky in Ukraine, Major-General Pyotr Krasnov in the Don, ViceAdmiral Alexander Kolchak in Russia, Vice-Admiral Miklós Horthy in Hungary), and, finally, international military and diplomatic support from neighboring monarchies, for instance, the German Empire and the Kingdom of Sweden in the case of Finland, the German Empire and the Austro-Hungarian Empire in the cases of Ukraine and Don, and we can also consider, in a certain sense, the Kingdom of Romania in the case of Hungary. The monarchist counter-revolution developed at the periphery of each state (for example, in Finland, it was in Vaasa, in Hungary - Szeged, in Russia - Omsk), since the capitals were captured by the Bolsheviks. Admittedly, the monarchist counter-revolution was defeated in Russia, but, in Finland and Hungary, its victory had only a provisional character, since both Kingdoms existed without their kings due to Allied pressure.

Keywords: dissolution of empires, Bolshevism, monarchist counter-revolution, History of Finland, History of Hungary, History of Ukraine, History of Russia.

* Citation: Bondarenko, D. (2020). The Downfall of the Russian and Austro-Hungarian Empires and the Monarchist Counter-Revolution. In Quaestio Rossica. Vol. 8, № 3. P. 1010-1022. DOI 10.15826/qr.2020.3.509.

Цитирование: Bondarenko D. The Downfall of the Russian and Austro-Hungarian Empires and the Monarchist Counter-Revolution // Quaestio Rossica. Vol. 8. 2020. № 3. P. 1010-1022. DOI 10.15826/qr.2020.3.509.

(C) Bondarenko D., 2020

Quaestio Rossica • Vol. 8 • 2020 • № 3, p. 1010-1022 
Проводится сравнительный анализ распада Российской и Австро-Венгерской империй и роли революции и контрреволюции на территориях бывших империй. Выявляются причины возникновения и классификация монархической контрреволюции, а также анализируются ее результаты. Монархическая контрреволюция в Центральной и Восточной Европе возникла именно как реакция на советскую власть и большевизм как идеологию и политическую практику. Она не имела бы серьезной основы для появления в республиканский демократический период революции, предшествовавший большевизму. Факторами монархической контрреволюции были соответствующие традиции в обществе, наличие харизматичных военно-политических лидеров, исповедовавших монархические взгляды (генерал-лейтенант барон Карл Густав Маннергейм в Финляндии, генераллейтенант Павел Скоропадский в Украине, генерал-майор Петр Краснов на Дону, вице-адмирал Александр Колчак в России, вице-адмирал Миклош Хорти в Венгрии), и, наконец, международная военная и дипломатическая поддержка со стороны соседних монархий (Германии и Швеции - Финляндии, Германии и Австро-Венгрии - Украине и Дону, Румынии - Венгрии). Монархическая контрреволюция возникла на окраинах государств (Финляндии - в Ваaсе, Венгрии - в Сегеде, России - в Омске), поскольку столицы были захвачены большевиками. Она потерпела поражение в России, а в Финляндии и Венгрии одержала лишь временную победу, поскольку оба королевства существовали без короля по причине давления со стороны союзников.

Ключевые слова: распад империй; монархическая контрреволюция; большевизм; история Финляндии; история Венгрии; история Украины; история России.

The First World War led to radical geopolitical transformation in Central and Eastern Europe resulting from the dissolution of the Russian and the Austro-Hungarian Empires, which was accompanied by social revolution (as each monarchy was replaced by republican rule) and the selfdetermination of nations amid the dictates of the winners.

Even though monarchical rule dominated in Europe before the First World War, most newly independent states that emerged in Central and Eastern Europe as a result of the collapse of Russia and Austria-Hungary chose republican rule. As Sir Halford Mackinder highlighted, the First World War was a fight between conservative empires and democratic nations [Mackinder]. Indeed, while Germany had dominated Central and Eastern Europe (beginning with the Berlin Congress of 1878 and until the Brest-Litovsk treaty of 1918), monarchy was the main form of government of newly independent states in the region. After the victory of the Allied powers in the First World War, the situation changed radically and republican rule became widespread.

However, in the cases of Russia and Austria-Hungary, the dynasty contradicted the nation, i. e., their dynastic statehood prevented the princi- 
ple of national sovereignty inside the country and the national unification of neighboring states. For example, the existence of the Austro-Hungarian Empire delayed the finalization of the process of national unification for Germany, Italy, and Romania (which was reflected in the Romanian proclamation of a state of war against Austro-Hungary on 27 August 1916), and also the independence of Hungary, Czechia, and Croatia. Thus, as Oskar Jászi has pointed out, the process of the dissolution of the Austro-Hungarian monarchy was as natural as the process of state integration of European countries, such as Germany, Italy, Romania:

The same fundamental causes working for unity in the nationally homogeneous states worked toward dissolution in the ethnographical mosaic of the Habsburg Empire [Jászi, 1964, p. 7].

And, in this case, Ignác Romsics has emphasized that the irredentist goals of Romania, Serbia, and Italy caused the state breakdown of AustroHungary [Romsics, p. 51].

The Russian Empire, as a dynastic statehood, also hampered the independence of non-Russian nations, such as Finland, Poland, Lithuania, Georgia, Armenia, etc. Indeed, the existence of the Russian and AustroHungarian Empires produced states of divided nations, such as Poles, Ukrainians, Romanians, etc. Furthermore, the rivalry between Germany and Austria-Hungary, on the one hand, and Russia, on the other hand, caused state instability in Central and Eastern Europe and led to the First World War.

Not only Germany but also France and Great Britain strived for dominance in Central and Eastern Europe. European powers considered AustroHungary as a bulwark against Russian expansion towards the Balkans but Russia as a counterbalance to Germany and Austro-Hungary [Romsics, p. 44; Stadler, p. 178]. Nevertheless, during the war, the Allies came to believe that the power vacuum created by the collapse of Russia and Austria-Hungary should be filled by new nation-states in Central and Eastern Europe, oriented to Great Britain and France to prevent German and Russian influence in the region [Romsics, p. 30-31, 44; Bideleux, Jeffries, p. 322-323]. In this case, Halford Mackinder proposed to separate Germany and Russia by means of the establishment of a Middle Tier of newly independent states that emerged in the former Russian and Austro-Hungarian Empires (Lithuania, Poland, Czechoslovakia, Hungary) [Mackinder, p. 196-198].

Germany's aim in the First World War was to separate Russia from Europe through a belt of buffer states [Fischer, p. 376-377, 456-472, 479-487, 509, 534-562]: Finland, Lithuania, Poland, Ukraine, Georgia, i. e., to return Russia to its pre-Peter the Great boundaries of the "Moscow Grand Dukedom" [Сазонов, с. 273; Туполев, с. 53]. In 1915, Paul von Rohrbach wrote that according to the interests of European security, the Russian Empire must be broken up into several territories to reduce the threat of the "Russian Menace" attacking Central Europe. In this manner, Germany should sponsor the independence of Finland, Poland, and Ukraine [Meyer, p. 6364; фон Рорбах, c. 88, 106]. 
Thus, the German aim was to minimize Russian influence in the Baltic region and to block it from accessing the Balkan, the Black Sea Region, and Asia Minor. This plan was realized after the Brest-Litovsk peace agreement: Russia was separated from Germany by Lithuania and Ukraine, and also from the Black Sea by Ukraine and the so-called South-Eastern Union of Cossack Hosts and Caucasus nations. The new buffer states such as the Kingdom of Finland, the Kingdom of Lithuania, and the Baltic Grand Duchy were bound to Germany by dynastic ties. Ukraine retained a republican government, because of the clash of interests between the German and AustroHungarian Empires. Since the latter tried to establish the Habsburg dynasty in Kiev (Archduke Wilhelm Habsburg), Germany, therefore, insisted on the establishment of Hetman rule as a historical form of government in Ukraine.

The defeat of the Russian Empire in the Great War would not have automatically led to its total disintegration, but only to certain territorial losses in Eastern Europe, and the deprivation of its imperial status. As in the case of Austria-Hungary, the satisfaction of the territorial demands of Romania, Serbia, and Italy would not have automatically meant the collapse of the Empire, without the Entente powers insisting on the total disintegration of the Dual Monarchy [Romsics, p. 31, 33-36, 44]. Most historians have previously argued that the dissolution of Austro-Hungary was inevitable, and its military defeat in the First World War only accelerated a process started by the Hungarian Revolution of 1848 and the Austro-Hungarian agreement of 1867, and furthered by the annexation of Bosnia and Hercegovina in 1908 [Stadler; Sked, 1981; Mason; Lieven, p. 177-198; Sked, 2001].

Thus, two of the most important factors in the downfall of these empires are as follows: an external one (the First World War and irredentism of the neighboring nation-states), and an internal one (secessionism of the incorporated nations). Meanwhile, the First World War was only the background that accelerated the process of their dissolution, followed by social revolution ${ }^{2}$.

The revolutionary processes in Russia and Austria-Hungary had some differences. First and foremost was the issue of abdication. In Russia, on 2 (15) March 1917, Nicholas II signed the Manifesto of abdication without the resolution of the Senate (the Supreme Court) and the Russian Parliament, i. e., in violation of the Constitution of 1906 (Articles 7, 26, 49) [Основные государственные законы, с. 457-459]. Meanwhile, in Austria-Hungary, Karl I did not abdicate the throne, he only refused to participate in public affairs of Austria by the Declaration of 11 November 1918 [Rauchensteiner, p. 993-1002, 1005; Шимов, с. 565] and also in Hungary by the Declaration of 13 November 1918. The absence of the formal abdication of the Emperor of Austria and King of Hungary created the opportunity for the restoration of the monarchy in Hungary. Even in Russia, it was still possible after the assassination of Nicholas II by the Bolsheviks,

${ }^{2}$ An overview of the modern discussion on the Russian revolution see: [Поршнева, Ульянова]. 
since some of the Romanovs, for instance, Grand Duke Pavel (an uncle of Nicholas II), Grand Duke Nicholas (an uncle of Nicholas II and the former Commander-in-chief of Russian Imperial Army), and Grand Duke Kyrill (a cousin of Nicholas II) could have inherited the Russian throne.

Hereafter was the proclamation of the republic. In Russia, it was a decision by the Provisional Government (not by parliament) on 1 (14) September 1917, ahead of the convening of the Constituent Assembly. In Austria-Hungary, by contrast, legislative bodies continued to work and made the declarations on this issue: Austria on 12 November 1918, and Hungary on 16 November 1918.

The disintegration of Austria-Hungary occurred very quickly, even before the proclamation of Austria and Hungary as republics. De facto it started on 28 October 1918 (the declaration of independence of Czechoslovakia), and, on 1 November 1918, the Empire was completely dissolved. Meanwhile, the process of the disintegration of the Russian Empire took a longer period (March - November 1917) and developed according to Miroslav Hroch's pattern, i. e., national mobilization - autonomy - the independent state [Hroch, p. 22-23, 26-28, 178-185]. For instance, in March 1917, the Provisional Government recognized the independence of Poland [Wandycz, p. 199] and autonomy of Estonia and Latvia [Церетели, с. 77], but other national issues, including the independence of Finland, were postponed until the Constituent Assembly. It should also be noted that the motto of the Russian revolution was "Russia is Federative and Democratic!", and the Constituent Assembly proclaimed Russia as a so-called Democratic Federative Republic, though this did not stop any centrifugal tendencies. So, Maurice Paléologue remarked:

Finland, Livland, Estland, Poland, Lithuania, Ukraine, Georgia, Siberia demand independence, or at least complete autonomy. That Russia is doomed to federalism, it is likely... But the current movement is far more secessionist than regional, more secessionist than federalist; it seeks neither more nor less as a national breakdown... The French Revolution began with the declaration of the Republic of one and indivisible. The Russian Revolution is taking a slogan: Russia is divided and fragmented [Палеолог, c. 402-403].

However, the dissolution culminated after the Bolshevik coup d'état and was caused not only by the Declaration of the Rights of the Peoples of Russia, issued by the Bolshevik government (the Council of People's Commissars) on 2(15) November 1917, but also by the Bolshevik anti-human ideology and political practice. Indeed, it was the result of an exodus of nations from Bolshevism [Pipes, p. 514-515; Булдаков, с. 417]. Generally, during 1918-1919, the collapse of both the above-mentioned Empires led to the formation of 33 new states on the territory of the former Russian Empire (January 1918) [Pipes, p. 514-515].

The Bolsheviks' main goal was to destroy all nation-states and create the World Soviet Republic [Декреты Советской власти, т. 1, с. 40; Милюков, 1925, c. 185-187] through the so-called "export of the revolution" or the "triumphal march of Soviet power" from the center (Russia) to the neighbors: Finland (27 January 1918), Ukraine (9 February 1918, 14 March, and 
14 December 1919), Latvia (6 January and 17 December 1918). Moreover, the establishment of Soviet power in Hungary on 21 March 1919 became a further stimulus for the spread of Bolshevism, for instance, on 7 April 1919, the Bavarian Soviet Republic was proclaimed. The Bolsheviks established the Third (Communist) International, as Pavel Milyukov remarked, "as a preliminary measure to conquest the world" [Miliukov, p. 8].

The counter-revolution in Russia, Finland, and Hungary emerged on the periphery of these states, as a counterbalance to their revolutionary capitals, and as a response to the Bolshevik regime. For example, since the Bolsheviks controlled the capitals (Petrograd in Russia, Helsinki in Finland, Budapest in Hungary), then the Headquarters of the White governments were located in Vaasa in Finland; Szeged in Hungary; Samara, Ufa and then Omsk in Russia, etc. In the Russian case, there was the central White government in Omsk, in addition to local ones in Arkhangelsk (the Northern government), Pskov (the North-Western government), and Taganrog (the Government of South Russia). According to Pavel Milyukov's conception, the counter-revolution had two periods: the preparation and the struggle, i. e., the latent and the active phases [Милюков, 1927, с. 4]. However, it is more accurate to state that there were three stages of counter-revolution: the emergence, the struggle (Civil War), and, according to its result, either the restoration (Finland and Hungary) or the defeat (Russia). In Sergei Melgunov's opinion, the reason for the defeat of counter-revolution was determined by the geographical factor. The Bolsheviks occupied the industrial centre while the Whites were concentrated and developed on the peripheries [Мельгунов, с. 16].

The success of the counter-revolution was closely linked to international support and, in particular, Anti-Bolshevik intervention. For example, Oszkár Jászi pointed out that the counter-revolution was in reply to the dictatorship of the proletariat and moral dissolution in society under Bolshevik leadership, but the Hungarian counter-revolution took the opportunity to liberate the country only simultaneously with Romanian intervention [Jászi, 1969, p. 153]. However, in István Deák's view, the Bolshevik regime was defeated by a popular nation-wide counter-revolution, and the Romanian intervention only accelerated this process [Deák, 129140]. The role of German intervention in Finland in 1918 is still open to debate too. For instance, most Finnish historians believe that German intervention played a certain, though not decisive, role in the liberation of Finland from the Reds. German aid only accelerated the end of the war, because, after the Brest-Litovsk peace treaty, the Russian Bolsheviks were keen to avoid any direct military confrontation with German forces in the country [Jussila, Hentila, Nevakivi, p. 119; Puntila, p, 109].

Most contemporary Russian and Ukrainian historians consider the counter-revolution in Russia as a single phenomenon, without dividing it into monarchist and republican components. The very term Monarchist counterrevolution was invented by Leon Trotsky and, initially, it had a pejorative meaning concerning some prominent Russian Whites leaders (Admiral Alexander Kolchak, General Nikolai Yudenich, General Eugene Miller) 
[Троцкий, с. 68]. Valentina Zimina and Yuri Grazhdanov used the term Germanophil Monarchist Counter-revolution to define the restoration regimes in the Ukrainian State, the Almighty Don Host, the Crimea, and the Baltic Grand Duchy in 1918 [Зимина; Гражданов, Зимина]. Indeed, there were two types of the Russian monarchist movement of 1918 after the Brest-Litovsk peace treaty: a Germanophil, which tried attempted to restore the monarchy in Russia through the German political and military support (for example, General Pyotr Krasnov, Prince Anatol von Liven, Duke Nicholas von Leuchtenberg, etc.) and a pro-Entente, one which relied on the Allies (for example, such as Generals Eugene Miller and Nikolai Yudenich, Admiral Alexander Kolchak, etc.).

The monarchist counter-revolution in Central and Eastern Europe (19181920 ) should be classified into three types. The first type was classical dynastic royalism, which meant the restoration of the overthrown dynasty. Such a type was widely represented among the Russian Whites (General Nikolai Yudenich, General Eugene Miller, Duke Nicholas von Leuchtenberg, Prince Anatol von Liven, Prince Pavel Bermondt-Avalov, etc.) The second type was national royalism, as an attempt to unite loyalty to the nation and loyalty to the throne, i. e. the establishment of a national monarchy (Admiral Miklós Horthy de Nagybánya in Hungary, Pehr Evind Svinhufvud af Qvalstad in Finland, Admiral Alexander Kolchak in Russia). And, the third type, conditionally called export-monarchism (i. e., export-counter-revolution), was the desire of the leadership of new states (it did not matter the monarchical or republican form of government) to liquidate Bolshevism and to restore the monarchy i Russia as a mean ensuring the security and independence of one's own state (Baron Carl Gustaf Emil Mannerheim, the Regent of the Kingdom of Finland; Pavlo Skoropadsky, the Hetman of the Ukrainian State; Pyotr Krasnov, the Ataman of the Almighty Don Horst) [Маннергейм, c. 177-178; Скоропадский, с. 11, 13, 15, 17, 27-28, 105-106; Краснов, с. 193].

The factors involved in the emergence of monarchical counterrevolution were, thus:

- Monarchical traditions. For instance, Finns, Lithuanians, Hungarians, and Russians had a long historical experience of monarchical statehood.

- Charismatic political and military leaders of new states who profess monarchical views, for example, Lieutenant-General Baron Carl Gustaf Emil Mannerheim in Finland, Lieutenant-General Pavlo Skoropadsky in Ukraine, Major-General Pyotr Krasnov in Don, Vice-Admiral Alexander Kolchak in Russia, Vice-Admiral Miklós Horthy in Hungary. Baron Carl Gustaf Emil Mannerheim was elected as a Regent of the Kingdom of Finland on 12 December 1918, after the abdication of King Frederich Karl [Маннергейм, с. 142-143, 145-147, 151; Jussila, Hentila, Nevakivi, p. 124-125; Puntila, p. 112-113]. Miklós Horthy was elected as a Regent of the Kingdom of Hungary by the National Assembly on 1 March 1920, after the evacuation of Romanian troops from Hungary [Horthy, p. 130-131; Szilassy, p. 71].

- International support from neighbouring monarchies was conducted through the intervention of diplomatic, or military-technical support. For example, in the Russian case, holding advantageous positions near Viborg 
and Narva, the German troops could have taken Petrograd and overthrown the Bolshevik power in Russia, but because of intensive battle activity on the Western Front, the German political establishment decided to provide only military-technical and diplomatic support to the Russian monarchists under the condition of their abidance of the terms of the Brest-Litovsk peace treaty [von der Goltz, s. 48, 91-92; фон Куль, Дельбрюк, с. 50, 52-54].

Supporting Russian monarchist groups, Graf Wilhelm von Mirbach-Harff, the German Ambassador to Russia, believed that Germany should thereby eliminate or minimize the influence of the Entente on the Russian counterrevolution. He planned the Anti-Bolshevik conspiracy in Moscow through a secret monarchist counter-revolutionary organization ("the Right Centre") led by Active Privy Councillor, Alexander Krivoshein, and Alexander Trepov, the former Prime-Minister of the Russian Empire [Документы Германского посла в Москве, с. 121-125, 127-129]. Presumably, the assassination of Graf Wilhelm von Mirbach-Harff in Moscow, committed by agents of the Cheka, was a preventive action by the Bolshevik government to foil Germany's plans. Even though the assassination of the Ambassador was a potential casus belli, Germany did not declare war on Soviet Russia, and merely closed its Embassy in Moscow, retaining only its Consulate General in Petrograd.

International support imposed certain obligations and limitations on independent foreign policy activity. For example, after signing an additional protocol to the Brest-Litovsk agreement on 27 August 1918, Germany prevented the Kingdom of Finland from attacking Petrograd.

Some new states such as Finland, Ukraine, Don, Estonia, became bases for the monarchist counter-revolution in Russia [Ахтамзян, с. 99-100, 125, 139, 159; Германская восточная политика, с. 137; Kirby, p. 56; Документы германского посла в Москве, с. 126; Зайцов, с. 130, 132, 140, 148; Kenez, p. $135,140,147,162,219-220,238-240,272]$. Their leaders believed that the liquidation of Bolshevism's threat and the restoration of the monarchy in Russia was the basis of a return to normal international relations, and would secure the territorial integrity and security of the new states [Маннергейм, с. 177-178; Мери, с. 118-119, 124-126, 128; Краснов, с. 215-216, 218, 220223; Россия и Украина, с. 259; Скоропадский, с. 11, 13, 15, 17, 27-28, 105106]. As it turned out, this goal was not realized due to the uncompromising position of the Russian White government (Supreme Ruler Admiral Alexander Kolchak) regarding its recognition of the newly independent states (Finland and Estonia) and the delimitation of new frontiers [Колчак и Финляндия, c. $87,93,97-98,100,113-114,117,119-121,135,137-140]$. It was Admiral Alexander Kolchak's uncompromising position that caused the Finnish and Estonian troops to stop their involvement in the advance towards Petrograd, which allowed the Reds to defeat General Yudenich. As Ernest von Wahl noted, the Russian White Forces lost the Civil War against Bolshevism because of their unwillingness to recognize the new political reality after the collapse of the Russian Empire [фон Валь, 1937, с. 12, 41, 54, 56].

The defeat of the monarchist counter-revolution in Russia was related to the defeat of Germany in the First World War. According to Arseny Zajtsov, 
11 November 1918 was "the mourning day of the Russian counter-revolution", since "the Armistice Day did not become the beginning of the world struggle against Bolshevism" [Зайцов, с. 333-334]. Pavel Milyukov also drew attention to the fact that the victory of the Entente did not provide the Whites with the opportunity to defeat the Reds in Russia [Милюков, 1927, с. 16, 75].

Germany and Finland failed to restore the monarchy in Russia, while the restoration of the monarchy in Hungary took place due to the victory of the Romanian army over the Hungarian Reds, since the Hungarian White troops were too weak to operate independently against them [Bernard, Kliment, p. 32, 34; Preda, Prodan, p. 148, 156-157; Ormos, p. 244-252, 309-310, 354-355; Romsics, p. 110-111]. However, after the Reds' collapse, the western and southern parts of the country were liberated by the Hungarian White Army, under the command of Vice-Admiral Miklós Horthy [Szilassy, p. 66; de Daruvar, p. 79].

In the summer of 1919, Archduke Joseph August proclaimed himself as a regent of the Kingdom of Hungary but was forced to abdicate after only two weeks. The Allies would not recognize him, as he represented the Habsburgs [Ormos, p. 334, 339, 343-344, 372]. Finally, faced by the strong opposition of the Entente to seeing the legitimate Hungarian sovereign, King Karl IV, restored to his throne, on 1 March 1920, the National Assembly elected Vice-Admiral Miklós Horthy, the Commander-in-chief of the Hungarian National Army, as a Regent of the Kingdom of Hungary [de Daruvar, p. 79]. In March and October 1921, Karl's attempts to regain the throne in Budapest were rejected by Horthy's government, which was conscious of the real threat of intervention by the Allies. Thus, due to Allied pressure, the Kingdom of Hungary now existed without a king.

The downfall of the Russian and Austro-Hungarian Empires occurred because of their dynastic statehood. The First World War was only the background and the accelerator of this process, accompanied by social revolution, which led to the establishment of the Bolshevik regime in Russia and Hungary, as a new challenge to the international order.

Generally, monarchist counter-revolution in the new states of these former empires did not emerge immediately after the downfall of their monarchies and the establishment of republican rule, but only subsequently, as a response to Bolshevism.

Finally, monarchist counter-revolution was victorious in Finland and Hungary thanks to the monarchical political tradition of society, charismatic leaders, and international support, but was defeated in Russia, due to a lack of international support and the unwillingness of the Russian Whites' government to recognize newly independent states. As Ernest von Wahl stressed, only an alliance of the new nations, which emerged after the imperial breakdown, would have destroyed the Bolshevik regime [фон Валь, с. 8-10, 12, 43, 48, 52, 54-56].

\section{Список литературы}

Ахтамзян А. А. От Бреста до Киля. Провал антисоветской политики германского империализма в 1918 году. М. : Изд-во ИМО, 1963. 220 с. 
Булдаков В. П. Война империй и кризис имперства: к социокультурному переосмыслению // Россия и Первая мировая война. СПб. : Дмитрий Буланин, 1999. C. 406-418.

Валь Э. Г. Фон Значение и роль Украины в вопросе освобождения России от большевиков на основании опыта 1918-1920 гг. Таллинн : [Б. и.], 1937. 71 с.

Германская восточная политика в Новое и Новейшее время. Проблемы истории и историографии. М. : Наука, 1974. 280 с.

Гражданов Ю. Д., Зимина В. Д. Союз орлов: Белое дело России и германская интервенция в 1917-1920 гг. Волгоград : Изд-во ВАГС, 1997. 280 с.

Декреты Советской власти : в 9 т. М. : Госполитиздат, 1957. Т. 1. 626 с.

Документы Германского посла в Москве Мирбаха // Вопр. ист. 1971. № 9. С. 120-129.

Зайцов А. А. 1918: очерки истории русской Гражданской войны. М. : Кучково поле, 2006. 368 с.

Зимина В. Д. Крах германофильской монархической контрреволюции на Юге России в годы Гражданской войны и интервенции. Калинин : [Б. и.], 1989. 87 с.

Колчак и Финляндия // Красный архив. 1929. Т. 2 (33). С. 82-144.

Краснов П. Н. Веселимое Войско Донское // Архив Русской революции : в 22 т. М. : Терра : Политиздат, 1991. Т. 5. С. 190-321.

Куль Д. бон, Дельбрюк Г. Крушение германских наступательных операций 1918 г. М. : Госвоениздат, 1935. 351 с.

Маннергейм К. Г. Э. Мемуары. М. : Вагриус, 1999. 508 с.

Мельгунов С. П. Гражданская война в освещении П. Н. Милюкова : (По поводу «Россия на переломе») : критико-библиогр. очерк. Париж : Rapid-Imprimerie, 1929. 91 с.

Мери В. Карл Густав Маннергейм - маршал Финляндии. М. : Новое лит. обозрение, 1997. 208 с.

Милюков П. Н. Национальный вопрос (Происхождение национальности и национальные вопросы в России). Прага : Свободная Россия, 1925. 192 с.

Милюков П. Н. Россия на переломе: большевистский период Русской революции : в 2 т. Париж : [Б. и.], 1927. Т. 2. Антибольшевистское движение. IX, 281 с.

Основные государственные законы // ПС3. Собр. 3. Т. 26. Отд. 1. 1906. СПб. : Гос. тип., 1909. С. 456-461.

Палеолог М. Царская Россия накануне революции. М. ; Петроград : Госиздат, 1923. $472 \mathrm{c}$.

Поршнева О. С., Ульянова С. Б. «Уроки Октября»: проблемы научного осмысления российской революции 1917 года и исторической памяти о ней // Новейшая история России. 2018. № 3 (8). С. 761-770. DOI 10.21638/11701/spbu24.2018.315.

Рорбах П. фон. Война и германская политика. М. : Изд. Г. А. Лемана и С. И. Сахарова, 1915. XIV, 107 с.

Россия и Украина. Из дневников Н. М. Могилянского и писем к нему П. П. Скоропадского (1919-1926) // Минувшее. Вып. 14. 1993. С. 253-274.

Сазонов С. Д. Воспоминания. М. : Междунар. отношения, 1991. 398 с.

Скоропадский П. П. «Украина будет!» Из воспоминаний // Минувшее. Вып. 17. 1994. С. 7-115.

Троцкий Л. Д. Между империализмом и революцией. М. : Директ-Медиа, 2015. 249 с.

Туполев Б. М. Россия в военных планах Германии // Первая мировая война: пролог ХХ века. М. : Наука, 1998. С. 49-53.

Церетели И. Г. Воспоминания о Февральской революции : в 2 кн. Париж : Mouton, 1963. Кн. 2. 429 с.

Шимов Я. В. Австро-Венгерская империя. М. : ЭКСМО, 2003. 609 с.

Bernard D., Ch. Kliment Ch. Magyar Warriors. The History of the Royal Hungarian Armed Forces, 1919-1945 : 2 Vols. Solihull : Helion \& Company, 2015. Vol. 1. 404 p.

Bideleux R., Jeffries J. A History of Eastern Europe. Crisis and Change. N. Y. : Routledge, 2007. 720 p.

Daruvar Y. de The Tragic Fate of Hungary. München : Danubia-Druckerei, 1974. 235 p.

Deák I. Budapest and the Hungarian Revolutions of 1918-1919 // The Slavonic and East European Rev. Vol. 46. 1968. № 106. P. 129-140. 
Fischer F. Germany's Aims in the First World War. N.Y. : W. W. Norton \& Co., 1967. 652 p. Goltz R. von der. Meine Sendung in Finnland und im Baltikum. Leipzig : K. F. Koehler, 1920. VIII, $312 \mathrm{~S}$.

Horthy N. Memoirs. Safety Harbor : Simon Publ., 2000. 348 p.

Hroch M. Social Preconditions of National Revival in Europe : A Comparative Analysis of the Social Composition of Patriotic Groups Among the Smaller European Nations. N. Y. : Cambridge Univ. Press, 1985. 229 p.

Jászi O. The Dissolution of the Habsburg Monarchy. Chicago ; L. : Univ. of Chicago Press, 1964. $482 \mathrm{p}$.

Jászi O. Revolution and Counter-revolution in Hungary. N. Y. : Howard Fertig, 1969. 240 p. Jussila O., Hentila S., Nevakivi J. From Grand Duchy to A Modern State. A Political History of Finland Since 1809. L. : C. Hurst \& Co., 1995. 398 p.

Kenez P. Civil War in South Russia, 1918. The First Year of the Volunteer Army. Berkeley; Los-Angeles ; L. : Univ. of California Press, 1971. 416 p.

Kirby D. Finland in the Twentieth Century. L. : Hurst \& Co., 1979. 263 p.

Lieven D. Empire. The Russian Empire and Its Rivals. N. Haven; L. : Yale Univ. Press, 2000. $486 \mathrm{p}$.

Mackinder H. Democratic Ideals and Reality. A Study in the Politics of Reconstruction.

N. Y. : Henry Holt \& Co., 1919. 266 p.

Mason J. The Dissolution of the Austro-Hungarian Empire, 1867-1918. L. ; N. Y. : Routledge, 1997. 140 p.

Meyer H. Rohrbach and His Osteuropa // The Russian Rev. Vol. 2. 1942. № 1. P. 60-69.

Miliukov P. Bolshevism: An International Danger; Its Doctrine and Its Practice Through

War and Revolution. L. : G. Allen \& Unwin, 1920. 303 p.

Ormos M. From Padua to the Trianon, 1918-1920. Boulder : Social Science Monographs, 1990. 409 p.

Pipes R. The Russian Revolution. N. Y. : Vintage Books : A Division of Random House, 1991. $976 \mathrm{p}$.

Preda D., Prodan C. Romania in WWI. A Concise History. Saarbrücken : Lambert Academic Publ., 2012. 188 p.

Puntila L. The Political History of Finland, 1809-1966. L. : Heinemann, 1975. 248 p.

Rauchensteiner M. The First World War and the End of the Habsburg Monarchy, 19141918. Wien ; Köln ; Weimar : Böhlau Verlag, 2014. 1181 p.

Romsics I. The Dismantling of Historic Hungary: The Peace Treaty of Trianon, 1920. Boulder ; Wayne ; N. Y. : Social Science Monographs, 2002. 201 p.

Sked A. Historians, the Nationality Question, and the Downfall of the Habsburg Empire // Transactions of the Royal Historical Society. 1981. Vol. 31. P. 175-193.

Sked A. The Decline and Fall of the Habsburg Empire, 1815-1918. L. : Longman, 2001. 360 p.

Stadler K. The Disintegration of the Austrian Empire // J. of Contemporary History. 1968. № 3. P. 177-190.

Szilassy S. Revolutionary Hungary, 1918-1921. Astor Park, FL : Danubian Press, 1971. 141 p.

Wandycz P. The Price of Freedom: A History of East Central Europe from the Middle Ages to the Present. L. ; N. Y. : Routledge, 1993. 330 p.

\section{References}

Akhtamzyan, A. A. (1963). Ot Bresta do Kilya. Proval antisovetskoi politiki germanskogo imperializma v 1918 godu [From Brest to Kiel. The Failure of the Anti-Soviet Policy of the German Imperialism in 1918]. Moscow, Izdatel'stvo Instituta mezhdunarodnykh otnoshenii. $220 \mathrm{p}$.

Bernard, D., Kliment, Ch. (2015). Magyar Warriors. The History of the Royal Hungarian Armed Forces, 1919-1945. 2 Vols. Solihull, Helion \& Company. Vol. 1. 404 p.

Bideleux, R., Jeffries, J. (2007). A History of Eastern Europe. Crisis and Change. N. Y., Routledge. 720 p.

Buldakov, V. P. (1999). Voina imperii i krizis imperstva: $\mathrm{k}$ sotsiokul'turnomu pereosmysleniyu [The War of the Empires and the Crisis of Imperialism: The Social-Cultural Reconsideration]. In Rossiya i Pervaya mirovaya voina. St Petersburg, Dmitrii Bulanin, pp. 406-418. 
Daruvar, Y. de (1974). The Tragic Fate of Hungary. München, Danubia-Druckerei. 235 p.

Deák, I. (1968). Budapest and the Hungarian Revolutions of 1918-1919. In The Slavonic and East European Rev. Vol. 46. No. 106, pp. 129-140.

Dekrety Sovetskoi vlasti $v 9 t$. [The Decrees of Soviet Power. 9 Vols.]. (1957). Moscow, Gospolitizdat. Vol. 1. 626 p.

Dokumenty Germanskogo posla v Moskve Mirbakha [The Documents of von Mirbach, German Ambassador in Moscow]. (1971). In Voprosy istorii. No. 9, pp. 120-129.

Fischer, F. (1967). Germany's Aims in the First World War. N. Y., W. W. Norton \& Co. 652 p.

Germanskaya vostochnaya politika $v$ Novoe i Noveishee vremya. Problemy istorii i istoriografii [The German Eastern Politics in Modern and Contemporary Period. The Problems of History and Historiography]. (1974). Moscow, Nauka. 280 p.

Goltz, R. von der. (1920). Meine Sendung in Finnland und im Baltikum. Leipzig, K. F. Koehler. VIII, $312 \mathrm{~S}$.

Grazhdanov, Yu. D., Zimina, V. D. (1997). Soyuz orlov. Beloe delo Rossii i germanskaya interventsiya $v$ 1917-1920 gg. [The Alliance of the Eagles. The White Affair of Russia and the German Intervention in 1917-1920]. Volgograd, Izdatel'stvo Volgogradskoi akademii gosudarstvennoi sluzhby. $280 \mathrm{p}$.

Horthy, N. (2000). Memoirs. Safety Harbor, Simon Publ. 348 p.

Hroch, M. (1985). Social Preconditions of National Revival in Europe. A Comparative Analysis of the Social Composition of Patriotic Groups Among the Smaller European Nations. N. Y., Cambridge Univ. Press. 229 p.

Jaszi, O. (1964). The Dissolution of the Habsburg Monarchy. Chicago, L., Univ. of Chicago Press. 482 p.

Jászi, O. (1969). Revolution and Counter-revolution in Hungary. N. Y., Howard Fertig. 240 p. Jussila, O., Hentila, S., Nevakivi, J. (1995). From Grand Duchy to A Modern State. A Political History of Finland Since 1809. L., C. Hurst \& Co. 398 p.

Kenez, P. (1971). Civil War in South Russia, 1918. The First Year of the Volunteer Army. Berkeley, Los Angeles, L., Univ. of California Press. 416 p.

Kirby, D. (1979). Finland in the Twentieth Century. L., Hurst \& Co. 263 p.

Kolchak i Finlyandiya [Kolchak and Finland]. (1929). In Krasnyi Arhiv. Vol. 2 (33), pp. 82-144.

Krasnov, P. N. (1991). Veselimoe Voisko Donskoe [The Almighty Don Host]. In Arkhiv Russkoi revolyutsii v 22 t. Moscow, Terra, Politizdat. Vol. 5, pp. 190-321.

Kuhl, H. von, Delbrück, H. (1935). Krushenie Germanskikh nastupatelnykh operatsii $1918 \mathrm{~g}$. [The Crash of German Offensive Operations 1918]. Moscow, Gosvoenizdat. 351 p.

Lieven, D. (2000). Empire. The Russian Empire and Its Rivals. N. Haven, L., Yale Univ. Press. 486 p.

Mackinder, H. (1919). Democratic Ideals and Reality. A Study in the Politics of Reconstruction. N. Y., Henry Holt \& Co. 266 p.

Mannerheim, K. G. E. (1999). Memuary [Memoirs]. Moscow, Vagrius. 508 p.

Mason, J. (1997). The Dissolution of the Austro-Hungarian Empire, 1867-1918. L., N. Y., Routledge. $140 \mathrm{p}$.

Mel'gunov, S. P. (1929). Grazhdanskaya voina v osveshchenii P. N. Milyukova. (Po povodu "Rossiya na perelome"). Kritiko-bibliograficheskii ocherk [The Civil War in Milyukov's View. (On "Russia at a Turning Point"). A Critical Bibliographical Essay]. Paris, Rapid-Imprimerie. $91 \mathrm{p}$.

Meri, V. (1997). Karl Gustav Mannerheim - marshal Finlyandii [Carl Gustaf Mannerheim, Marshal of Finland]. Moscow, Novoe literaturnoe obozrenie. 208 p.

Meyer, H. (1942). Rohrbach and His Osteuropa. In The Russian Rev. Vol. 2. No. 1, pp. 60-69.

Miliukov, P. (1920). Bolshevism: An International Danger; Its Doctrine and Its Practice Through War and Revolution. L., G. Allen \& Unwin. 303 p.

Miliukov, P. N. (1925). Natsional'nyi vopros (Proiskhozhdenie natsional'nosti $i$ natsional'nye voprosy $v$ Rossii) [The National Question (The Origin of the Nation and National Question in Russia)]. Prague, Svobodnaya Rossiya. 192 p.

Miliukov, P. N. (1927). Rossiya na perelome: bol'shevistskii period Russkoi revolyutsii $v 2 t$. [Russia in the Crisis: The Bolshevik Period of the Russian Revolution. 2 Vols.]. Paris, S. n. Vol. 2. Antibol'shevistskoe dvizhenie IX, $281 \mathrm{p}$. 
Ormos, M. (1990). From Padua to the Trianon, 1918-1920. Boulder, Social Science Monographs. 409 p.

Osnovnye gosudarstvennye zakony [The Basic State Law]. (1909). In PSZ [Complete Collection of Laws of the Russian Empire]. Collection 3. St Petersburg, Gosudarstvennaya tipografiya. Vol. 26. Department 1. 1906, pp. 456-461.

Paleologue, M. (1923). Tsarskaya Rossiya nakanune revolyutsii [The Tsarist Russia on the Eve of Revolution]. Moscow, Petrograd, Gosizdat. 472 p.

Pipes, R. (1991). The Russian Revolution. N. Y., Vintage Books, A Division of Random House. 976 p.

Preda, D., Prodan, C. (2012). Romania in WWI. A Concise History. Saarbrücken, Lambert Academic Publ. $188 \mathrm{p}$.

Puntila, L. (1975). The Political History of Finland, 1809-1966. L., Heinemann. 248 p.

Porshneva, O. S., Ulyanova, S. B. (2018). "Uroki Oktyabrya": problemy nauchnogo osmysleniya Rossiiskoi revolyutsii 1917 goda i istoricheskoi pamyati o nei ["Lessons of October": Problems of Scientific Understanding and Historical Memory of the Russian Revolution of 1917]. In Noveishaya istoriya Rossii. Vol. 8. Iss. 3, pp. 761-770. DOI 10.21638/11701/spbu24.2018.315.

Rauchensteiner, M. (2014). The First World War and the End of the Habsburg Monarchy, 1914-1918. Wien, Köln, Weimar, Böhlau Verlag. 1181 p.

Rohrbach, P. von. (1915). Voina i germanskaya politika [The War and the German Politics]. Moscow, Izdaniye G. A. Lemana i S. I. Sakharova. XIV, 107 p.

Romsics, I. (2002). The Dismantling of Historic Hungary: The Peace Treaty of Trianon, 1920. Boulder, Wayne, N. Y., Social Science Monographs. 201 p.

Rossiya i Ukraina. Iz dnevnikov N. M. Mogilyanskogo i pisem k nemu P. P. Skoropadskogo (1919-1926) [Russia and Ukraine. From N. M. Mogilyansky's Diaries and P. P. Skoropadsky's Letters to Him (1919-1926)]. (1993). In Minuvshee. Iss. 14, pp. 253-274.

Sazonov, S. D. (1991). Vospominaniya [Memoirs]. Moscow, Mezhdunarodnye otnosheniya. $398 \mathrm{p}$.

Shimov, Ya. V. (2003). Avstro-Vengerskaya imperiya [The Austro-Hungarian Empire]. Moscow, EKSMO. 609 p.

Sked, A. (1981). Historians, the Nationality Question, and the Downfall of the Habsburg Empire. In Transactions of the Royal Historical Society. Vol. 31, pp. 175-193.

Sked, A. (2001). The Decline and Fall of the Habsburg Empire, 1815-1918. L., Longman. 360 p.

Skoropadsky, P. P. (1994). “Ukraina budet!" Iz vospominanii [“There will be Ukraine!" Excerpts from Memoirs]. In Minuvshee. Iss. 17, pp. 7-115.

Stadler, K. (1968). The Disintegration of the Austrian Empire. In J. of Contemporary History. No. 3, pp. 177-190.

Szilassy, S. (1971). Revolutionary Hungary, 1918-1921. Astor Park, FL, Danubian Press. $141 \mathrm{p}$.

Trotsky, L. D. (2015). Mezhdu imperializmom i revolyutsiei [Between Imperialism and Revolution]. Moscow, Direkt-Media. 249 p.

Tsereteli, I. G. (1963). Vospominaniya o Fevral'skoi revolyutsii v $2 \mathrm{kn}$. [The Memoirs on the February Revolution. 2 Books]. Paris, Mouton. Book 2. 429 p.

Tupolev, B. M. (1998). Rossiya v voennykh planakh Germanii [Russia in the Germany's War Plans]. In Pervaya mirovaya voina: prolog XX veka. Moscow, Nauka, pp. 49-53.

Wahl, E. G. von. (1937). Znachenie i rol' Ukrainy v voprose osvobozhdeniya Rossii ot bol'shevikov na osnovanii opyta 1918-1920 gg. [The Significance of Ukraine in Russia's Liberation from the Bolsheviks on the Basis of the Experience of 1918-1920]. Tallinn, S. n. 71 p.

Wandycz, P. (1993). The Price of Freedom: A History of East Central Europe from the Middle Ages to the Present. L., N. Y., Routledge. 330 p.

Zaitsov, A. A. (2006). 1918: ocherki istorii Russkoi Grazhdanskoi voiny [1918: Essays on the History of the Russian Civil War]. Moscow, Kuchkovo Pole. 368 p.

Zimina, V. D. (1989). Krakh germanofil'skoi monarkhicheskoi kontrrevolyutsii na Yuge Rossii v gody Grazhdanskoi voiny i interventsii [The Collapse of the Germanophile Monarchist Counter-Revolution in the South of Russia during the Civil War and Intervention]. Kalinin, S. n. 87 p. 